\title{
APPLICABLE LAW FOR CONTRACTS IN THE SPORTING CONTEXT
}

\section{Ines Medić}

Faculty of Law, University in Split, Croatia, ines.medic@pravst.hr

DOI: 10.1515/seeur-2017-0014

\section{Abstract}

This article presents an analysis of contractual relations in sport from the standpoint of the Croatian legislative system. Due to the complexity of the subject matter, the author considers only a small fragment of it - the significance and the role of sport in Croatian society and the law of contracts „as a cornerstone on which ,sports law" has been built and which is of primary importance in most areas where there is an interface between sport and the law, irrespective of whether the sport is being played at an elite level or at a more humble one“.

Bearing in mind the limited extent of this article, the autor tries to provide some clarifications and some guidance on how to deal with the designation and the determination of the applicable law for contracts in the sporting context. Considering that there are different legal regimes which may come into play with regard to the designation of the law applicable to contracts in the sporting context, the author first presents the determination of the applicable law according to the Rome I Regulation and then according to the Croatian Arbitration Act, Swiss Private International Law Act and the CAS Code of Sports-related Arbitration, as the most common in sports practice. Then, the author deals with contracts concluded with minor athletes and the determination of the law applicable to some preliminary questions.

Finally, the author presents her perception of the problems encountered and some suggestions for the improvement of the existing legal framework. 
Keywords: sports contracts, applicable law, CAS Code, Rome I Regulation, Croatia

\section{Introduction}

Sport today is a potentially highly profitable activity which draws into its auspices multiple investors looking for profit. Considering the objective circumstances, the public sector in Croatia is very rarely able to compete with the terms offered by different non-institutional investors. ${ }^{1}$ Even more so because, unlike most other business affairs, investment in sport, particularly in the sports development of minor athletes, presents a long term investment without any guarantee not only in profit, but also in the return of the means invested. Having in mind the Croatian economic reality and the fact that small investors (predominate in Croatia) who invest in one or a small number of players have disproportionately high expences, ${ }^{2}$ it is not unusual to have foreign investors financially following the sports development of minor athletes.

On the other hand, considering the significance and the role of sport in Croatian society, the hiring of foreign athetes to play for domestic clubs it is not unusual either. It is hard to take a general position on the cost effeciveness of such investments since there are examples for and against it, although we support the tendency towards the preference for the development of home grown players. ${ }^{3}$

Regardless of whether they are minor or adult domestic athletes whose development is financially supported by foreign investors or minor or adult foreign athletes hired by domestic clubs, every such arrangement which involves a foreign element opens certain questions which can only be answered through an application of private international law provisions.

\footnotetext{
${ }^{1}$ With regard to Croatia, see: Ivančić-Kačer, B.: Športski ugovori maloljetnika, posebno s aspekta mjerodavnog prava, Zbornik radova Pravnog fakulteta u Splitu, god. 47, 2/2010, p. 440.

2 Ibidem, p. 444.

${ }^{3}$ More on the subject see in: Freeburn. L.: European Football's Home-Grown Players Rules and Nationality Discrimination Under the European Community Treaty, Marquette Sprots Law review, Vol. 20, Issue 1 Fall, 2009, pp. 177-221; Miettinen, S./Parrish, R.: Nationality Discrimination in Community Law: An Assessment of UEFA Regulations Governing Player Eligibility for European Club Competitions (The Home-Grown Player Rule), 5 ESLJ xiv 2007, Retrieved from http://heinonline.org, 10 November 2011; Minderhoud, P./Oosterom-Staples, H.: Obstacles to free movement of young workers, European network on free movement of workers, January 2011, pp. 8-10.
} 
Although there is a Sports Act in Croatia, ${ }^{4}$ it does not envisage any special legal treatment for contracts in the sporting context. Since there is no unique body of substantial law for contracts in the sporting context, but rather some standard principles of law from different fields adapted to fit the sporting context, ${ }^{5}$ specific provisions of private international law for the sporting context also do not exist. There is a limited number of stricto sensu private international law provisions which are applicable in a sporting context, but they do not reflect their real significance. As can be inferred from what has already been said, sport is closely connected to commerce. Obviously for a long time, as Baron de Coubertin first stated: „We are exporting rowers, runners, fencers: it is a free trade of the future...". ${ }^{6}$ Consequently, private international law provisions actually represent an important part of international sports law. ${ }^{7}$ There are also provisions regarding nationality, relevant in the case of athletes with two or more nationalities or (rarely) without nationality, ${ }^{8}$ provisions on legal capacity and capacity to act, ${ }^{9}$ provisions on parent-child relations relevant in the case of minor athletes ${ }^{10}$ and the plethora of other provisions which are considered as general provisions of private international law, such as formal validity, ${ }^{11}$ public policy, ${ }^{12}$ renvoi, ${ }^{13}$ etc. Although they formally do not belong in stricto sensu to private international law provisions, this list should be accompanied by special substantial rules ${ }^{14}$ and overriding mandatory rules ${ }^{15}$ which are also applicable in the international context, including international sporting context.

\footnotetext{
${ }^{4}$ Zakon o sportu, NN RH No 71/06, 150/08, 124/10, 124/11, 86/12, 94/13, 85/15, 19/16.

${ }^{5}$ Sullivan, A.: The Role of Contract in Sports Law, Australian and New Zealand Sports Law Journal, 2010 5(1), p. 3.

${ }^{6}$ De Coubertin, P.: Selected writings - Olympism, IOC Lausanne, 2004, p. 604.

${ }^{7}$ See: Regulation (EC) No 593/2008 of the European Parliament and of the Council of 17 June 2008 on the law applicable to contractual obligations (hereafter: Rome I Regulation), OJ EU L 177, of 4 July 2008.

${ }^{8}$ Arts. 11 and 12 of Croatian Private International Law Act (hereafter: Croatian PILA), NN RH No 53/91.

${ }^{9}$ Art. 14 of Croatian PILA, Art. 13 of Rome I Regulation.

${ }^{10}$ Art. 40 of Croatian PILA.

${ }^{11}$ Art. 11 of the Rome I Regulation.

${ }^{12}$ Art. 21 of the Rome I Regulation.

${ }^{13}$ Art. 20 of the Rome I Regulation.

${ }^{14}$ See: different provisions of Law of Foreigners (NN RH No 130/11, 74/13) which deal with admittance, residence and work of foreigners, including sportsmen, in Croatia.

${ }^{15}$ See: Art. 85(2) of Family Law Act (NN RH No 103/15) and Art. 53(1) of Notaries Public Act (NN RH No 78/93 29/94, 162/98, 16/07, 75/09) with regard to minor sportsmen.
} 


\section{The Role Of Contract In Sports Law}

Contract as a legal ground of most diverse categories of relations is inherent to many legal branches, including the sports law. ${ }^{16}$ Undoubtedly, the law of contracts presents ,a cornerstone on which „sports law“ has been built and which is of primary importance in most areas where there is an interface between sport and the law", irrespective of whether the sport is being played at an elite level or at a more humble one. ${ }^{17}$

Because the emergence of the sports contract includes all the usual actions and conditions as in any other contract, it is obvious that their differentia specifica lies not in their formation, but in their subjects and obligations. ${ }^{18}$ There is a great diversity of sports related contracts. They range from a contract between the athlete and a club (standard player contract), between the athlete and respective federation or a contract connected to the athlete's primary activity (e.g. sponsorship contract, ${ }^{19}$ insurance contract), contracts regarding management between athletes and their managers, contracts regarding participation rights and obligations in major events or competitions to very complex contracts, like contracts for the sale of media rights in respect of a sporting event or competition, contracts regarding the rights to host a major sporting competition, etc. In other words, the term ,sports related contracts“ should be understood ,to include all stipulations related to manifold aspects of sport, whether they touch upon the proper athletic activities and ensuing obligations on the part of performers and organisers, or deal with exploitation of rights stemming from their broadcast, circulation, pulication, etc. “. ${ }^{20}$

Increasingly commonly, sports related contracts include an international element. ${ }^{21}$ That implies an application of private international law provisions with regard to the determination of the applicable law for contract and possible

\footnotetext{
${ }^{16}$ See: Momčinović, H.: Ugovori (općenito), in: Crnić, I./Ćurković, M./Gliha, I./IvančićKačer, B./Ivkošić, M./Kačer, H./Labar, B./Mateša, Z./Mijatović, N./Mintas-Hodak, Lj./ Mimčinović, H./Perkušić,, A./Petrović, S./Primorac, D.: (Uvod u) Športsko pravo, Inženjerski biro, Zagreb, 2009, p. 9.

${ }^{17}$ Sullivan, op. cit., note 5, p. 3.

${ }^{18}$ Hrabar, M.: Sportski ugovori maloljetnika, Zagrebačka pravna revija, Vol. 3, No. 2 , August 2014, p. 171.

${ }^{19}$ See: Sponzorski ugovori: Zašto tvrtke daju milijune eura za mjesto na dresovima? Retrieved from http://arhiva.dalje.com/hr-sport/sponzorski-ugovori--zasto-tvrtke-daju-milijune-eura-za-mjesto-na-dresovima/374131 , 15. 10. 2016., Augustine-Schlossinger, L.: Legal Considerations for Sponsorship Contracts of Olympic Athletes, Jeffrey S. Moorad Sports L.J., Vol. 10, Issue 2, 2003, pp. 281-296.

${ }^{20}$ Serio, M.: Sports Contracts in Italy, Amicus Curiae, Issue 84, Winter 2010, p. 25.

${ }^{21}$ Sullivan, op. cit., note 5, p. 4.
} 
preliminary questions. However, due to the ,specificity of sport" ${ }^{\text {“22 }}$ and the well developed body of autonomous sports rules ${ }^{23}$ some of the sports related contracts ${ }^{24}$ contain a clause on the application of lex sportiva. ${ }^{25}$ In such cases, applicable (state) law applies only additionally in order to deal with questions not covered by the lex sportiva.

On the top of that, most of those contracts also include an arbitration clause. ${ }^{26}$ It is because statutes of almost all sport federations provide for arbitration procedure and limit or prohibit recourse to national courts. ${ }^{27}$ In order to participate in the game, athletes have no choice but to accept those rules. ${ }^{28}$ In this case, applicable law will be determined according to the rules of the

\footnotetext{
${ }^{22}$ See: CAS 2007/A/1358 FC Pyunik Yerevan v. C., AFC Rapid Bucaresti and FIFA, paras. 104-105; TAS 2005/A/902 Mexès and AS Roma v. AJ Auxerre, TAS 2005/A/903 AJ Auxerre v. Mexès and AS Roma, paras. 122-141.

${ }^{23}$ Including the organization's constitution, stautes, disciplinary regulations, competition rules, licencing regulations, anti-doping rules, etc. See: Reilly, L.: Introduction to the Court of Arbitration for Sport (CAS) \& the Role of National Courts in International Sports Disputes, An Symposium, Journal of Dispute Resolution, Vol. 2012, Issue 1, 2012, p. 69. ${ }^{24}$ It is the case with (almost) all players' contracts, contracts between the athlete and the club, athlete and the federation and contracts regarding management between athletes and their managers.

${ }^{25}$ What is understood as lex sportiva see in: Siekmann, R.C.R.:/Soek, J. (eds.): Lex Sportiva: What is Sports Law, ASSER International Sports Law Series, T.M.C. Asser Press, The Hague, 2012; Galantić, M.: Lex sportiva - poreklo i značaj termina, Teme, No. 2, April-June 2015, pp. 559-577; Foster, K.: Lex sportiva, Transnational Law in Action, The International Sports Law Journal, 2008/3-4, pp. 3-11; Nafziger, J.A.R.: Lex Sportiva, The International Sports Law Journal, 2004/1-2, pp. 3-8; Valero, A.: In search of a working notion of lex sportiva, The International Sports Law Journal, 2014/14, pp. 3-11; Davis, T.: What Is Sports Law?, Marq. Sports L. Rev., Vol. 11, Issue 2, Spring, 2001, pp. 211-244. ${ }^{26}$ See: Steingruber, A.M.: Sports Arbitration: Determination of the Applicable Regulations and Rules of Law and Their Interpretation, The International Sports Law Journal, 2008/3-4, pp. 54-68; Momčinović, H.: Športska arbitraža i rješavanje sporova u vezi sa športom, in: Crnić, I./Ćurković, M./Gliha, I./Ivančić-Kačer, B./Ivkošić, M./Kačer, H./Labar, B./Mateša, Z./Mijatović, N./Mintas-Hodak, Lj./Mimčinović, H./Perkušić,, A./Petrović, S./Primorac, D.: (Uvod u) Športsko pravo, Inženjerski biro, Zagreb, 2009, p. 298-303.

${ }^{27}$ There are some exceptions, though. For example, according to Art. 26 of the Croatian Regulations on the status of handball players (Propisnik o statusu rukometaša) of 21 December 2006, if the player and the club have concluded a civil contract, all the disputes between the player and the club or the third party, arising from such contract are to be solved before the competent court. Or, according to Art. 6 of Registrations' Regulations (Registracijski pravilnik) of 19 August 2016 of Croatian Volleyball Federation, only the disputes regarding players' financial claims may be brought in front of competent state court.

${ }_{28}$ Panagiotopoulos, D. P.: Lex sportiva and international legitimacy governing: protection of professional players, US-China Law Review, Vol. 8:121, 2011, pp. 130-131.
} 
respective (federation's) arbitral tribunal ${ }^{29}$ or Croatian Arbitration Act. ${ }^{30}$ Alternatively, since the ultimate arbitral tribunal in sports related disputes is the Court of Arbitration for Sport (CAS), ${ }^{31}$ the law appliable to the merits is determined according to the Swiss Private International Law Act (hererafter: PILA) $)^{32}$ and/or the CAS Code of Sports-related Arbitration. ${ }^{33}$ Namely, CAS arbitrations are governed by Chapter 12 of the Swiss PILA if, at the time of the conclusion of the arbitration agreement, at least one of the parties had neither their domicile nor their habitual residence in Switzerland. ${ }^{34}$

In the following text, we will deal with the determination of the applicable law from the point of view of the Croatian legal system, lex sportiva excluded. Thus, we will first present the determination of the applicable law according to Rome I Regulation and than according to the Croatian Arbitration Act, Swiss Private International Law Act (hererafter: PILA) ${ }^{35}$ and the CAS Code of Sports-related Arbitration ${ }^{36}$ as the most common in sports practice. Finally, we will deal with contracts concluded with minor athletes and the determination of the law applicable to some preliminary questions.

29 E.g., Arbitral rules of sports arbitral tribunal at Croatian Olympic Comitee, of 25 August 1999.

${ }^{30}$ Zakon o arbitraži, NN RH No 88/01. According to Art. 1(1) and (3) of Part one, this Act applies to any arbitration if the seat of the arbitral tribunal is in Croatia, including the one with an international element. According to Art 2(1)/7 - ,internationaly attributed dispute“ any dispute in which at least one of the parties has its residence or habiteual residence abroad or is a legal enity established according to foreign law. Thus, the internationality of the dispute lies in an objective circumstances and not in the parties agreement on the nature of the dispute.

${ }^{31}$ Established in Lausanne, Switzerland.

${ }^{32}$ Federal Act on Private International Law of 18 December 1987, as amended until 1st July 2014 (English translation available at www.andreasbucher-law.ch ). Chapter 12, Art. 176(1) - „The provisions of this chapter apply to any arbitration if the seat of the arbitral tribunal is in Switzerland and if, at the time arbitration agreement was entered into, at least one of the parties had neither its domicile nor its habitual residence in Switzerland“".

${ }^{33}$ In force as from 1 January 2016.

${ }^{34}$ Chapter 12, Art. 176(1) PILA - „The provisions of this chapter apply to any arbitration if the seat of the arbitral tribunal is in Switzerland and if, at the time arbitration agreement was entered into, at least one of the parties had neither its domicile nor its habitual residence in Switzerland".

${ }^{35}$ Federal Act on Private International Law of 18 December 1987, as amended until 1st July 2014 (English translation available at www.andreasbucher-law.ch ).

${ }^{36}$ In force as from 1 January 2016. 


\section{Rome I Regulation}

\section{General rule}

Within the "internal market" (Croatia included), it is the Rome I Regulation ${ }^{37}$ that establishes a uniform regime of conflict-of-laws rules applicable to contractual obligations. Regulation maintains party autonomy as a general principle ${ }^{38}$ so, according to Art. 3(1) of the Regulation, parties to a contractual relationship linked to more than one legal system are free to determine the law applicable to their contract by an agreement. ${ }^{39}$ This general principle has been confirmed by the CJEU case law in Intercontainer Interfrigo ${ }^{40}{ }^{\text {which }}$ clearly states that a uniform set of rules established by the Rome Convention enshrines the principle that priority is given to the intention of the parties.

Normally, choice is agreed upon expressly $y^{41}$ but there is also a posibility of a tacit (implicit) choice (where it can be ,clearly demonstrated by the terms of the contract or the circumstances of the case $\left.{ }^{\text {" }}\right){ }^{42}$ Therefore, an implicit choice of law is also allowed on the condition that it is real and undoubtedly emerges

${ }^{37}$ Regulation (EC) No 593/2008 of the European Parliament and of the Council of 17 June 2008 on the law applicable to contractual obligations (hereafter: Rome I Regulation), OJ EU L 177, of 4 July 2008. Entered into force on 23 July 2008 and applies to contracts concluded after 17 December 2009.

${ }^{38}$ Heiss, H.: Party autonomy. In Ferrari, F., Leible, S. (eds.), Rome I Regulation, The Law Applicable to Contractual Obligations, Sellier, European law publishers GmbH, Munich, 2009, p.1.

${ }^{39}$ On the benefits of such approach see: Wilderspin, M./Plender, R.: The European Private International Law of Obligations, 4th ed., Sweet \& Maxwell, London, 2014, para. 6-002 and Zhang, M.: Party Autonomy and Beyond: an International Perspective on Contractual Choice of Law, Emory IInt'1 L. Rev.. 20, 2006, p. 511.

${ }^{40} \mathrm{C}-133 / 08$ Intercontainer Interfrigo SC (ICF) v Balkende Oosthuizen BC, ECLI:EU:C:2009:9687.

${ }^{41}$ At the same time, one has to keep in mind that the court may," in the light of all the facts, find that the parties have made a real choice although this is not expressly stated in the contract". For example, if the contract is in a standard form which is known to be governed by a particular system of law or based on a prevoius course of dealing between the parties in case of acceptance of the content of the contract or in case of acceptance of general terms of contract if the circumstances do not indicate deliberate change of policy by parties. See:

Giuliano, M./Lagarde, P.: Report on the Convention on the law applicable to to contractual obligations, OJ EZ C 282, form 31 October 1980., p. 17. Also, if the contract contains a provision on a law applicable to interpretation, in most of the jurisdiction it will be considered as a choice of law provision. See: Staudingers Kommentar zum Bürgerlichen Gesetzbuch, 14th ed., 2011, pp. 64, 89.

${ }^{42} \mathrm{E}$.g. if there is an express choice of law provision in an ancillary contract that might be considered relevant for the main contract or an earlier practices between the parties based on contracts containing an applicable law provision, etc. 
from the terms of contract or circumstances of the case. Considering that there is a low probability that any of the indicators standing alone will meet the requiremets of „reasonable certainty“, ${ }^{43}$ an implicit choice of law test always includes an assessment of two group of indicators: terms of contract and the circumstances of the case. ${ }^{44}$ According to Giuliano/Lagarde Report, with regard to the terms of contract, competent authority has to evaluate: legal nature of the contract, existance of the prorogation clause, use of standard form of the contract and referral to legal provision(s) of a certain country contained in the contract. With regard to the circumstances of the case, the competent authority has to evaluate: correlation of the contract with an earlier practice based on the choice of applicable law and earlier commercial practice based on the contract which entails the choice of law clause..$^{45}$ In the case of the existence of mutually incompatible indicators, the court should restrain from making an assumptions and move to objective connecting factors, i.e. subsidiary applicable law. This type of situation will not occur very often in a sport related context since most of those contracts include an express choice of law clause.

In the case of a doubt on consent and material validity of the contract or any other term of the contract (e.g. choice of law clause), according to Art. 10(1) of the Rome I Regulation, the law which would govern the contract if the contract or the terms were valid (lex contractus) applies. Nevertheless, if a party (e.g. an athlete) ${ }^{46}$ claims that s/he did not consent s/he may rely upon

\footnotetext{
${ }^{43}$ According to some Croatian authors, based on the research of Croatian legal practice, it is only the prorogation of jurisdiction clause that may carry such weight, so the courts should be advised to accept this clause as an independent indicator of the „reasonable certainty“ test. See: Župan, M.: Pravo najbliže veze u hrvatskom i europskom međunarodnom privatnom pravu, Rijeka, 2006, p. 94. But, it may be so only in case of an express and exclusive prorogation agreement. See: Lando, O./Nielsen, P.A.: Rome I Regulation, 45 CMLR 6 (2008), p. 1699; Martiny, D. in: Münchener Kommentar zum BGB, Vol. 10, 6th ed., C. H. Beck, München, 2015, p. 50. See also case law of High Commercial Court of Croatia: Pž867/03-3 of 3 October 2006 and Pž-3031/06-5 of 20 September 2007.

${ }^{44}$ Župan, op. cit., note 43, pp. 92-93.

${ }^{45}$ Giuliano/Lagarde, op. cit., note 41, p. 21. According to some authors, competent court should, in addition, also evaluate following indicators: common residence or nationality of the parties in the dispute, the fact that (out of a few potentially applicable laws) only one of them supports validity of the contract and the place of performance (as defined in the contract). Hill, J.: Choice of law in contract under the Rome Convention: The approach of the UK courts, ICLQ, Vol. 53, April 2004, p. 331.

${ }^{46}$ Of course, it may be any party but most often it will be an athlete due to the fact that, especially standard players contracts, are made in the standard form that is drafted by the federations for general use and no derrogatory clause is allowed. For instance, an arbitration clause may be a part of the contract, which in practice forbids any recourse to the state
} 
the law of the country in which s/he has their habitual residence to establish that $\mathrm{s} /$ he did not consent, but only if the circumstances clearly point out that it would not be reasonable to determine the effect of their conduct in accordance with lex contractus (Art. 10(2)). According to Giuliano/Lagarde Report, this means that the court ,must have regard to all the circumstances of the case, not soley to those in which the party claiming that $\mathrm{s} /$ he has not consented to the contract has acted". ${ }^{47}$

Parties are allowed to choose any state $\operatorname{law}^{48}$ as the applicabe law for their contract, irrespecive of any connection between the contract and the chosen law. ${ }^{49}$ The only limitation refers to the choice of ,non-state"laws (e.g. lex mercatoria or general principles of law, etc.). However, according to Recital 13, application of a non-state body of law (as a conflictual choice) remains possible within the limits of mandatory provisions of the state-law applicable to the contract. ${ }^{50}$ This limitation does not refer to the contracts which contain an arbitration clause, as most sport related contracts do, as will be discussed infra.

Most often, the chosen law will be applicable to the entire contract, but there is also a possibility of dépeçage (severability). However, one must keep in mind that severability might lead to mutually exclusive or inconsistent choices. ${ }^{51}$ If the chosen laws cannot be logically reconciled, recourse will be taken to Art. 4 - applicable law in the absence of choice. Due to potential difficulties, severability is rarely encouraged, even though in the case of complex contracts ${ }^{52}$ which are separable (e.g. hosting of a major sporting

justice at all or before all disputes have been ruled on by arbitral tribunals instituted by national federations.

${ }^{47}$ Giuliano/Lagarde, op. cit., note 41, p. 28.

${ }^{48}$ See: Mankowski, P.: Die Rom I-Verordnung - Änderungen in europäischen IPR für Schuldverträge, Internationales Handelsrecht, 2008, pp. 133, 136 and Leible, S./Lehmann, M.: Die Verordnung über das auf vertragliche Schuldverhältnisse anzuwenende Recht (,,Rom I), RIW, 2008, p. 533.

${ }^{49}$ Garcimartín Alférez, F.J. (2008), The Rome I Regulation: Much ado about nothing?, The European Legal Forum, Section I, 2008, p. 66

${ }^{50}$ See: Kondring. J.: Nichtstaatliches Recht als Vertragsstatut vor staatlichen Gerichten - oder: Privatkodificationen in der Abseitsfalle, IPRax, 2007, p. 241; Reimann, M.: Was ist wälbahres Recht?, in: Verschraegen, B. (ed.): Rechtswahl - Grenzen und Chancen, Jan Sramek Verlag KG, 2010, p. 1; Schinkels, B.: Die (Un-)Zulässigkeit einer kollisionsrechtlichen Wahl der UNIDROIT Principles nach Rom I, GPR, 2007, p. 106.

${ }^{51}$ Wojewoda, M.: Mandatory Rules in Private International Law, Maastricht J. Eur. \& Comp. L., Vol. 7, No. 2, 2000, p. 206.

${ }^{52}$ See, for example: Carducci, G.: Major infrastructure projects in EU private international law: jurisdiction and conflict of laws, Construction Law International, Vol. 8, No. 3, 
event by a particular city, commercial agreements concerning media rights, etc.), it might be welcome. ${ }^{53}$ Croatian practice shows that this option has been used sparingly. ${ }^{54}$

There are no limitations with regard to the time at which the choice of applicable law can be made Art. 3(2). A choice may be made at the time the contract is concluded, subsequently or an earlier choice can be changed subsequently. Depending on the will of the parties, such a choice may have a retroactive effect (ex nunc) or not (ex tunc). In order to avoid dealing with the double regime - one law applicable from the time the contract is concluded until the change of choice and the other one starting from the subsequent choice and onwards, it is much better to opt for the first option. In any case, none of the subsequent changes in the applicable law affects the formal validity of the contract nor does it affect the right of the third parties.

There are, though, some limitations which restrict parties' choice. Therefore, even if the parties have validly stipulated the applicable law to their obligations, certain considerations may justfiy a limited application of the chosen law. One of them is wholly ,internal“ circumstances. Thus, if the competent authority establishes that all of the elements are connected exclusively to Croatia, but the parties have agreed on the application of a foreign law, the effect of a foreign law should be limited to the ,incorporation of substantial provisions of a chosen law into a contract insofar as they are not contrary to the mandatory provisions of Croatian law" ${ }^{55}$ In other words, in domestic (sports) contracts it will not be possible to avoid mandatory provisions of national law with which there is an exclusive connection. The other limitation is designed to protect the Member States' and Community's interests in cases where the factual circumstances so justify. So, if all the relevant elements at the time of choice are located in one or more Member Sates, the effect of a chosen law should be limited by the mandatory provisions of Community law. ${ }^{56}$

\footnotetext{
2013, pp. 14-21.

${ }^{53}$ Such as in Don King Productions, Inc. v. Douglas, regarding tortious interference with contract brought by a boxing promoter against the then heavyweight champion of the world. See: Eisen, B.N.: Cross-training: Sports Litigation and the Conflict of Laws, Seton Hall Journal of Sport Law, Vol. 3, 1993, p. 53-55.

${ }^{54}$ Sajko, K.: Međunarodno privatno pravo, Narodne novine, Zagreb, 2009, p. 420.

${ }^{55}$ Kunda, I.: Pravo mjerodavno za ugovore o intelektualnom vlasništvu - od ZRSZ-a do Uredbe Rim I, Zbornik radova međunarodne naučne konferencije „Bosna i Hercegovina i Euro-Atlantske integracije - trenutni izazovi i perspektive“, Bihać, 2012, p. 322.

${ }^{56}$ See: CJEU Case C-381/98 Ingmar GB v. Eaton [2000] ECR I-9305, para. 25., Case C-184/12 [2013] Unamar NVv Navigation Maritime Bulgare ECLI:EU:C:2013:663, Case C-135/15 [2015] Nikiforidis ECLI:EU:C:2016:281. Medić, I.: Lex Contractus and Over-
} 


\section{Determination of the applicable law in the absence of choice}

Where parties did not use the possibility to choose the applicable law and it cannot be inferred with reasonable certainty from the terms of the contract or circumstances of the case, the applicable law is determined objectively by categorized types of contract. Thus, the first step is to establish whether the respective contract belongs to one of the cathegories enumerated in Art. $4(1)^{57}$ for which the hard and fast choice of law rules are provided.$^{58}$ If the answer is negative or the contract falls within more then one category, the law applicable is the law of the country of habitual residence of the party who has to perform it (Art. 4(2)) at the time of the conclusion of the contract (Art. 19). Where it is clear from all the circumstances of the contract that it is manifestly more closely connected with a country other than that provided for in those provisions, then the law of that other country shall apply (Art. 4(3)). If the law applicable cannot be determined pursuant to paragraphs 1 or 2, the law of the State with the closest connection (lex connexitatis) applies.

A special regime is provided for certain protected categories, such as individual employment contracts, consumers contracts, etc. The purpose of these regimes is to protect the weaker party and also to ensure predictability. ${ }^{59}$ Thus, an individual employment contract is governed by the law chosen by the parties, but such a choice may not have the result of depriving the employee of the protection afforded to them by mandatory provisions of the law of the country:

- in which or (failing that) from which the employee habitually carries out their work in performance of the contract,

- where the place of business through which the employee was engaged is situated,

- with which the contract is more closely connected, if the circumstances as a whole show that there is a closer connection with a country different than in the above cases.

In the absence of parties' choice, applicable is the law of the country in which

riding Mandatory Rules. What Can We Learn from the CJEU Case Law?, Book of Proceedings, 16th International Scientific Conference on Economic and Social Development - „The Legal Chalenges of Modern World“, Vol. 16, 2016, pp. 43-52.

${ }^{57}$ Contracts for: the sale of goods, provision of services, right in rem in immovable property or a tenancy of immovable property, franchise, distribution, sale of goods by auction, etc.

${ }^{58}$ Valdhans, J./Myšáková, P.: Rome I and Rome II Regulations - Alies or Enemies? Retrieved from https://www.law.muni.cz/sborniky/dp08/files/pdf/mezinaro/valdhans.pdf, 12. 11. 2016.

${ }^{59}$ In that sense, see: Case C- 29/10 Koelzsch v. Etat du Grand Duchy of Luxemburg [2011] ECR I-01595 and Case C-384/10 Voogsgeerd v. Navimer SA [2011] ECR I-13275. 
or (failing that) from which the employee habitually carries out their work in performance of the contract (Art. 8(2)), or (if it cannot be determined) the law of the conutry where the place of business through which the employee was engeged is situated (Art. 8(3)). If the contract is more closely connected with a third state, then the law of that country applies (Art. 8(4)).

It is not clear whether dépeçage is allowed also in the absence of choice of law. Doctrinary views differ on that question. While some argue that the Rome I Regulation no longer allows for depeçage in the absence of choice, ${ }^{60}$ some are strongly against this conclusion. ${ }^{61}$

Some general questions

According to Art. 9(1) of the Rome I Regulation, ,provisions the respect for which is regarded as a crucial by a country for safeguarding its public interests, such as political, social or economic organisation" cannot be contracted out to by the parties by choosing the law of another country. ${ }^{62}$ Their strictly compulsory nature requires their direct application irrespective of the governing law chosen by the parties or imposed by the relevant conflict rule. ${ }^{63}$ While the application of the overriding mandatory rules of the forum is not restricted, according to Art. 9(3), application of foreign overriding mandatory rules may be brought into play only if it is ,the law of the country were the obligations arising out of contract have to be or have been performed".

Public policy considerations are restricted to the domestic public policy. Thus, the court is allowed to refuse the application of provisions of the applicable law if it is manifestly incompatible with the ordre public of the forum.

The possibiliy of renvoi is explicitly excluded and any referral to the law applicable means referral to its substantial law provisions, private international law provisions excluded. It is irrelevant whether the applicable law is defined by the parties or through an objective connecting factor. ${ }^{64}$

${ }^{60}$ Van Calster, G.: European Private International Law, Hart Publishing, Oxford and Portland, 2013, p. 136.

${ }^{61}$ Magnus, U.: Article 4 Rome I Regulation: The Applicable Law in the Absence of Choice, in: Ferrari, A./Leible, S. (eds.): Rome I Regulation - The Law Applicable to Contractual Obligations in Europe, Sellier, Munich, 2009, p. 31.

${ }^{62}$ Kunda, I.: Defining Internationally mandatory Rules in European Private International Law of Contracts, Zeitschrift für Gemeinschaftsprivatrecht (GPR), 2007 (Vol. 4, No. 5), pp. 210-222.

${ }_{63}$ Pauknerová, M.: Mandatory rules and public policy in international contract law, ERA Forum, Vol. 11, 2010, p. 30; Van Bochove, L.M.: Overriding mandatory Rules as a Vehicle for Weaker Party Protection in European Private International Law, European Law Review, 2014 (No. 3), pp. 147-156.

${ }^{64}$ Sajko, op. cit., note 54, p. 418. 
If the parties have chosen the law of a state with more than one legal system, each of which has its own rules of law in respect to contractual obligations, each territorial unit shall be considered as a country for the purposes of identifying the law applicable. However, with regard to the conflicts of law solely between the units of such state, this rule may be disregarded ${ }^{65}$

With regard to the scope of the applicable law, according to Art. 12, the law applicable to the contract governs in particular: interpretation, performance, the consequences of a total or partial breach of obligations (including the assesment of damages in so far as it is governed by rules of law), the various ways of extinguishing obligations, and prescription and limitation of actions and the consequences of nullity of the contract. Only, in relation to the manner of performance and the steps to be taken in the event of defective performance, does the law of the country in which the performance takes place have to be taken into account. ${ }^{66}$

\section{Determination Of Applicable Law In Contracts With An Arbitration Clause}

As in all contracts, parties are free to choose applicable law for their sports related contract, but the choice of applicable law in contracts with an arbitration clause is even less limited than in contracts which contain state jurisidiction or have no jurisdiction clause. Namely, in contracts with an arbitration clause, party autonomy is wider since the choice of applicable law is not limited to state law. Therefore, the parties can also choose the applicability of a system of rules other than national law (e.g. Olympic Charter, International Federations statute, World Anti-doping Code, etc.) or general principles of law ${ }^{67}$ or even ex aequo et bono dispute resolution. ${ }^{68}$ In the case of a choice of a non-state law, it is important that it is relevant in the context of the case and that it "satisfyes the need of rationality, security and forseeability“. ${ }^{69}$.

\footnotetext{
${ }^{65}$ Art. 22 of the Rome I Regulation.

${ }^{66}$ Art. 12(2) of the Rome I Regulation.

${ }^{67}$ See: Panagiotopoulos, D.P.: General Principles of Law in International Sports Activities and Lex sportiva, International Sports Law Review Pandektis (ISLR/Pandektis), Vol. 10, No. 3-4, 2014, pp. 332-350.

${ }^{68}$ Sajko, op. cit., note 54, pp. 154-155; Sajko, K.: The Substantial Law Applicable to International Commercial Disputes According to Croatian Law and Arbitral Practice, Croatian Arbitral Yearbook, Vol. 1, 1994, p. 65; Sikirić, H.: Arbitraža uz primjenu načela pravičnosti-ex aequo et bono, Pravo u gospodarstvu, 1995, No 1/2, p. 91 et seq.

${ }^{69} \mathrm{CAS} 2006 / \mathrm{A} / 1123$ \& 1124 Al Gharafa SC v. P. Wantchope Watson and P. Wantchope Watson v. Al Gharafa SC.
} 


\section{Croatian Arbitration Act}

According to Art. 27(1) of the Croatian Arbitration Act, ${ }^{70}$ the arbitral tribunal must decide ,according to the rules of the law chosen by the parties“. Renvoi is expressly excluded so any referral to the law applicable is considered as a referral to its substantial rules, only. This is the law which governs interpretation, validity, emergence, termination and relations between the parties. In the absence of parties' choice, the law with which the action is most closely connected is applicable. ${ }^{71}$ Exceptionally, there is also a possibility of ex aequo et bono or en qualité d'amiable compositeur dispute resolution, but only if the parties expressly authorise the tribunal to do so. ${ }^{72}$ In any case, the tribunal will take into account all the contractual provisions as well as the applicable customs.

\section{Swiss Private International Law Act}

If the contract anticipates the jurisdiction of the Swiss arbitral tribunal, Chapter 12 of Swiss PILA applies, ${ }^{73}$ unless the parties opt for the CAS Code of sportsrelated Arbitration. According to Art. 187(1) PILA, the arbitral tribunal must decide ,according to the rules of the law chosen by the parties or, in the absence of such choice, according to the rules of law with which the action is most closely connected". Thus, if the parties have agreed on the applicable law, it will be considered a primary connecting factor. Choice of law is not limited to the state-law so parties can also agree on an application of a nonstate body of law, like lex sportiva. ${ }^{74}$ If the parties have not designated the applicable law, the arbitral tribunal cannot assume a choice of law based on the hypothetical will of the parties. ${ }^{75}$ With regard to the depeçage, parties are allowed to declare various laws as applicable to the contract.

Only in the absence of parties' choice the closest connection comes into account. According to the settled case law of the CAS this option has never been applied, ${ }^{76}$ due to the fact that the CAS case law considers the prorogation

\footnotetext{
${ }^{70}$ See note 30 .

${ }^{71}$ Art. 27(2) of the Arbitration Act.

${ }^{72}$ Art. 27(3) of the Arbitration Act.

${ }^{73}$ International Arbitration.

${ }^{74}$ Berger, B./Kellerhals, F.: International and Domestic Arbitration in Switzerland, 3rd ed., Hart Publishing, 2015, para. 1396.

${ }^{75}$ See: CAS 2006/A/1204, para. 6.5.

${ }^{76}$ Haas, U.: Applicable law in football-related diputes - The relationshio between the CAS Code, the FIFA Statutes and the agreement of the parties on the application of national law, CAS Bulletin, 2015/2, p. 9.
} 
agreement in favour of CAS as an implicit choice of law by the parties, i.e. an implicit choice of the CAS Code. ${ }^{77}$ This is rather unexpected solution, at odds with the former case in which (following the same line of reasoning) the explicit and the implicit choice of law coexist. According to the Swiss doctrine, this is not a problem since an explicit choice of law always takes precedence over an implicit choice of law, ${ }^{78}$ but it seems that CAS does not always agree with such view. Namley, in the Appeal Arbitration Procedure CAS Panels primarily apply the conflict of law rule in R58 of the CAS Code. ${ }^{79}$

In both cases, this referral should be taken as a referral to the Swiss substantive law provisions (Art. 14(1)). According to Art. 187(2), „the parties may authorize the arbitral tribunal to decide ex aequo et bono".

\section{CAS Code of sports-related Arbitration}

In the case where parties expressly opt for the CAS Code of sports-related Arbitration, ${ }^{80}$ law applicable to the merits will be determined according to the Code. The outcome will differ depending on the procedure, since in ordinary arbitration proceedings the chosen law is considered a primary connecting factor and in appeal proceedings only as a subsidiary option.

\section{ORDINARY ARBITRATION PROCEDURE}

According to R45 ${ }^{81}$ of the CAS Code of Sports -related Arbitration, ${ }^{82}$ law applicable to the merits in an Ordinary Arbitration Procedure is, primarily, the law chosen by the parties. Thus, if parties have chosen a law, such law has to be applied to decide on the merits of the dispute. According to CAS jurisprudence ${ }^{83}$ and the Swiss law, ${ }^{84}$ an implicit choice is also recognised

\footnotetext{
${ }^{77}$ CAS 2006/A/1204, para. 6.6..

${ }^{78}$ See: Berger/Kellerhals, op. cit., note 74, para. 139; Arroyo, M./Burckhardt, P.: Arbitration in Switzerland, The Practitioner's Guide, 2013, Art. 187, para. 22

${ }^{79}$ CAS 2014/A/3742, para. 38 et seq.; CAS 2014/A/3848, para. 37 et seq.; Haas, op. cit., note 76 , p. 10.

${ }^{80}$ See note 36.

${ }^{81}$ „The Panel shall decide the dispute according to the rules of the law chosen by the parties or, in the absence of such a choice, according to Swiss law. The parties may authorize the Panel to decide ex eaquo et bono."

${ }^{82}$ See note 36.

${ }^{83}$ CAS 2002/O/373 and CAS 2006/O/1127.
}

${ }^{84}$ Karrer, P.: Art. 187, in: Berti, S.V. (ed.): International Arbitration in Switzerland, The Hague, 2000, pp. 479-531, para. 88-89. 
under the same conditions as in the Rome I Regulation. ${ }^{85}$ Instead of choosing a state law, the parties may authorize the Panel to decide ex eaquo et bono (according to equity and fairness rather than according to specific legal rules).

In the absence of a choice, Swiss law applies, even if the case has no connection with Switzerland. It is explained in a way that, by choosing the CAS as a competent authority, parties also choose the CAS Code, which, in the absence of an explicit or implicit choice of law, refers to Swiss substantive law. ${ }^{86}$ Thus, if the parties opted for an arbitral tribunal the lex arbitri applies, i.e. the arbitration law at the seat of arbitration. This view has been criticised.$^{87}$

\section{APPEAL ARBITRATION PROCEDURE}

According to R58 ${ }^{88}$ of the same Code, law applicable to the merits in an Appeal Arbitration Procedure is, primarily, rules of the competent international sports organizations. Where these rules are unclear, incomplete or ambiguous, the Panel may resort to ,the rules of law chosen by the parties“. So, in this case, application of the law chosen by the parties may only be subsidiary. In other words, the parties' autonomy exists only within the limits set by the CAS Code. ${ }^{89}$

Considering that the rules of some international sports organizations contain reference to a national law, there is an open question on how to proceed in a case where there is also an explicit choice of law by the parties. Does this means that the chosen law should be completely ignored or there might be some room for its application? Unfortunately, CAS' jurisprudence does not offer a coherent answer to this question. The awards range from the complete ignorance of the chosen law $^{90}$ to the conclusion in favour if the co-existence of the two laws. ${ }^{91}$ According to the CAS jurisprudence, matters that remain

${ }^{85}$ CAS 2010/O/2237.

${ }^{86}$ CAS 2010/O/2237, para. 136.

${ }^{87}$ Rigozzi, A.: L'arbitrage international en matière de sport, Basel, Helbing Lichtenhahn, 2005, pp. 596-597, as referred by: Coccia, M.: International Sports Justice: The Court of Arbitration for Sport, European Sports Law and Policy Bulletin, 1/2013, p. 65.

${ }^{88}$ „The Panel shall decide the dispute according to the applicable regulations and, subsidiarily, to the rules of law chosen by the parties or, in the absence of such a choice, according to the law of the country in which the federation, association or sports-related body which has issued the challenged decision is domiciled or according to the rules of law that the Panel deems appropriate. In the latter case, the Panel shall give reasons for its decision“". ${ }^{89}$ See: CAS 2014/A/3527, para. 57; CAS 2014/A/3850, para. 51; CAS 2013/A/3309, para. 70, etc. Haas, op. cit., note 76, p. 12.

${ }^{90}$ See: CAS 2004/A/678, para. 5.3 et seq. and CAS 2013/A/3160, para. 71 et seq.

${ }^{91}$ See: CAS 2014/A/3383-3385, para. 49 et seq.; CAS 2014/A/3527, para. 56 et seq.; CAS 2014/A/3634, para 37, etc. 
subject to parties' autonomy include, for example, whether and under what conditions contract materialises, ${ }^{92}$ in accordance with which principles it is to be interpreted, whether and under what conditions the fulfilment of a contractual term can be evaded, ${ }^{93}$ whether a valid representation exists in connection with concluding the contract, etc. ${ }^{94}$

In the absence of a choice, the Panel is authorised to apply the „law of the coutry in which the federation, association or sports - related body which has issued the challenged decision is domiciled" or ,the rules of law it deems appropriate“. Due to the fact that many international federations are established in Switzerland, ${ }^{95}$ Swiss substantive law shoud be (and is) applied in these cases.

Since the Panel is also authorised to apply ,the rules of law it deems appropriate" ${ }^{96}$ it may apply other national laws, general principles of law or the so-called lex sportiva, ${ }^{97}$ but it has to give reasons for such decision..$^{98}$

In any case, a CAS Panel has to be aware of the Swiss public policy. Hence, it may decide to discard any of the applicable rules (including primarily applicable law), and apply subsidiary applicable law in order to preserve generally recognised Swiss legal values. ${ }^{99}$

\section{Separately Determined Issues}

When speaking of contracts, there are some issues which are not governed by lex contractus, but are unavoidable since they appear as preliminary questions, such as: characterization, habitual residence determination and the determination of legal capacity. In order to offer the „,complete picture“, we will briefly deal with each of those issues.

92 CAS 2013/A/3309, para. 84 et seq.; CAS 2013/A/3647 \& 3648, para. 101 et seq.

93 CAS 2013/A/3647 \& 3648, para. 113 et seq.

${ }^{94}$ Haas, op. cit., note 76, p. 16-17.

${ }^{95}$ For example: FIFA (International Footbal Federation), FIBA International Basketball Fedration), IHF (International Handball Federation), etc. For more see: Reilly, L.: Introduction to the Court of Arbitration for Sport (CAS) \& the Role of National Courts in International Sports Disputes, An Symposium, Journal of Dispute Resolution, Vol. 2012, Issue 1, 2012, p. 69.

${ }^{96}$ CAS 2006/A/1205 Mariano Puerta v. ITF, TAS 2005/A/983 \& 984 Club Atlético Peñarol. ${ }^{97}$ Coccia, M.: International Sports Justice: The Court of Arbitration for Sport, European Sports Law and Policy Bulletin, 1/2013, p. 66.

${ }^{98}$ See: CAS 2005/A/878 Club Guarani v. González Ferreira \& FC St. Gallen.

${ }^{99}$ Otherwise, the CAS award can be set aside by the Swiss Federal Tribunal. See: Judgment 4A_490/2009 of 13 April 2010 on CAS 2009/A/1765 Benfica Lisboa v. Atlético Madrid \& FIFA and Judgment 4A_558/20111 of 27 March 2012 on CAS 2010/A/2261-2263 Matuzalem \& Real Zaragoza v. FIFA. 


\section{Characterization $^{100}$}

Due to the diversity of sport related contracts it is very important to assign a factual situation to a proper legal category. Characterization deals with the process of determining the juridical nature (proper legal category) of a factual situation that requires decision. This general method certainly has its place within the sports law, since national legislators, as well as national federations, tend to use different approaches with regard to sport related contracts, especially standard player contracts (i.e. professional contracts). ${ }^{101}$ In some countries it is characterised as a labour law relationship while in some others it is characterised as a civil law relationship. ${ }^{102}$ There is a strong economic calculation behind it since civil law characterisation of such contracts enables employers to avoid protective labour legislation and consequently lots of financial and other obligations towards the athlete and the state. ${ }^{103}$

In order to deal with this issue, the concept of the term ,worker" within the ambit of the EU law is determined autonomously and is different than within national legislations. ${ }^{104}$ There is a number of CJEU judgments, ${ }^{105}$ which lead to the conclusion that any person who ,for a period of time performs services for and under the direction of another person in return for which he receives remuneration“, under the condition that this work is „effective and genuine“", is recognised as a worker under EU law. As such, the relatively wide definition of a worker has enabled the EU's institutions to define the

\footnotetext{
${ }^{100}$ Also known as classification by English writers and qualification by French writers.

${ }^{101}$ Detailed analysis see in: Bilić, A./Smokvina, V.: Ugovori između profesionalnih nogometaša i klubova - ugovori radnog ili građanskog prava?, Zbornik radova PF U Splitu, Vol. 49, 4/2012, pp. 831-862.
}

${ }^{102}$ Steiner, J./Woods, L.: EU Law, Oxford University Press, Oxford, 2009, p. 465.

${ }^{103}$ Schneider, M.: A Juridical Approach to the notion of Independent Labour. A Critical Study of the French and German Systemms, in: The International Journal of Labour Law and Industrial relations, Vol. 16/4, Kluwer Law International, 2000, pp. 337-347.

${ }^{104}$ Steiner/Woods, op. cit., note 89, p. 465.

${ }^{105}$ Court of Justice of the European Union. See: C-75/63 Hoekstra v. Bestuur der Bedrijfsvereniging voor Detailhandel en Ambachten, ECR [1964] 177, par. 177. i 184.; C-53/81 Levin v. Staatssecretaris van Justitie, ECR [1982] 1035, par. 13. i 14.; C-66/85 Lawrie-Blum v. Land Baden-Würteberg, ECR [1986] 2135, par. 17.; C-139/85 R.H.Kempf v. Staatssecretariat van Justitie, ECR [1986] 1741, par. 15.; C-357/89 Raulin v. Minister van Justitie Onderwijs en wetenschappen, ECR [1993] I-1027, par. 13., 15. i 19.;C-15/90 David Maxwell Moddleborough v. Chief Adjudication Officer [1991] ECR 4655, par. 13.; C-179/90 Merci convenzionali porto di Genova SpA v. Siderurgica Gabrielli SpA, ECR [1991] I-5889; C-85/96 Maria Martinez Sala v. Freiestaat Bayer, ECR [1998] I-2691, par. 32.; C- 456/02 Trojani v. Centre public d'aide sociale, ECR [2004] I-7573, par. 17 te C-14/09 Hava Genc v. Land Berlin, ECR [2010] I-000, par. 9., 19, 21.-28. te 33. 
relationship between the clubs and the athletes as a relationship between an employer and a worker (club being employer and an athlete being worker), ${ }^{106}$ which means that it is governed by labour law. Consequenly, any contract in connection with that relationship, should also be governed by labour law. ${ }^{107}$

Unfortunately, this refers to collective sports only and the athletes involved in individual sports (e.g. tennis, box, billiards) do not necessarily enjoy this protection. They have to, through an intermediary, or independently, negotiate on competitions in which they want to participate and the compensation they will get. Thus, EU law makes the difference between professional athletes in collective sports who are considered workers ${ }^{108}$ and professional athletes in individual sports which are characteried as self-employed persons. ${ }^{109}$

Consequently, the same line of distinction can be drawn in the private international law sphere. Namely, European private international law contains specific rules that aim to protect contracting parties that are usually considered to be the 'weaker party', such as consumers and employees. ${ }^{110} \mathrm{In}$ general, protection is provided in two ways: by establishing an 'objective' rule favouring the weaker party and by restricting party autonomy through the application of „overriding mandatory provisions“, which are superimposed on the law applicable to the contract to protect a fundamental interest of a Member State. ${ }^{111}$ Since the athletes in an individual sports, under the EU law, are not considered workers, they do not benefit from those provisions.

${ }^{106}$ See: C-66/85 Lawrie-Blum v. Land Baden-Würteberg, ECR [1986] 2135, par. 17. i C-179/90 Merci convenzionali porto di Genova SpA v. Siderurgica Gabrielli SpA, ECR [1991] I-5889.

${ }^{107}$ This means that, if there is an economic activity involved, they too have the right to exercise the freedom of movement, right of establishment and freedom to provide services. There are many CJEU's judgments which confirm this view: C-36/74 Walrave and Koch v. Association Union Cycliste Internationale, ECR [1974] 1405, par. 4; C-13/76 Gaetano Donà v. Mario Montero, ECR [1976] 1333, par. 12.; C-415/93 Union Royale Belge des Societés de Football Association and other v. Bosman, ECR [1995] I-4291, par. 73.; C-176/96 Lehtonen v. Fédération Royale Belge des Sociétés de Basket-ball (Belgian Royal Federation of Basketball Clubs - FRBSB) [2000], ECR I-2681; C- 438/00 Deutscher Handballbund eV v. Maros Kolpak [2003] ECR I-4135; C-256/03 Igor Simutenkov v. Ministerio de Educación y Cultura, Real Federación Española de Fùtbol [2005] ECR I-2579, par. 20.-27. te Joined cases C-51/96 i C-191/97 Christelle Deliège v. Francophone de Judo et disciplines Associeés Asb [2000] ECR I-2549, par. 41. i 54.

${ }^{108}$ Which receive compensation in the form of regular salary as well as bonuses, in compliance with the employment contract between the athlete and the club. (Art. 45. TFEU).

${ }^{109}$ Within the meaning of the free movement provisions this category of athletes is considered as a service provider. (Art. 57. TFEU).

${ }^{110}$ Arts. 6 and 8 of the Rome I Regulation.

111 Van Bochove, L.M.: Overriding mandatory Rules as a Vehicle for Weaker Party Pro- 


\section{Habitual residence}

Although habitual residence of one of the parties has become the most important connecting factor to determine the applicable law, Regulation does not offer a definition of the term. Obviously it relies on the existing CJEU case law, ${ }^{112}$ although the Court itself has pointed out that it cannot be directly transposed from one context to another. ${ }^{113}$ An exception is made with respect to situations concerning companies or other bodies (corporated or incorporated) or natural persons acting in the course of their business, determining their haitual residence by naming the place of central administration and the principal place of business respectively (Art. 19(1)).

\section{Legal capacity (Capacity to act)}

Question of legal capacity of natural persons or legal persons is not covered by lex contractus, so each Member State continues to apply its own private international law provisions to determine whether or not a person has the capacity to act. ${ }^{114}$ However, in order to protect a party acting in good faith, Art. 13 of the Rome I Regulation subjects the protection of the other party to the contract to very stringent conditions - the contract must be concluded between the persons who are in the same state, there must be a conflict of laws, the person claiming to be under a disability must be deemed to have full

tection in European Private International Law, European Law Review, No. 3, 2014, p. 147.

${ }^{112}$ For the purpose of uniform application of different European legal instruments, the Court underlined that the term ,habitual residence“ has an autonomus meaning under EU law. In that sense, see: Case C-452/93 Magdalena Fernández v. Commission [1994] ECR I-4295, para. 22; Case C-90/97 Swaddling v. Adjudication Officer [1999] ECR I-1075, para. 29; Case C-372/02 Adanez-Vega [2004] ECR/-10761, para. 37; Case C-66/08 Kozlowski [2008] ECR I-0000. Therefrom follows that it is the place in which the person concerned has established, with the intention that is should be of a lasting character, the permanent or the habitual center if his interests; whereat all the factual circumstances which constitute such residence must be taken into account. For the determination of habitual residence of a minor see: Case C-523/07 Applicant $A$ [2009] ECR I-2805; C-497/10 PPU Mercrediv. Chaffe [2010] ECR I-14309. According to this case law „habitual residence“ must be interpreted as a meaning that it correspond to the place which reflects some degree of integration by the child in a social and family environment. To that end, in particular the duration, regularity, conditions and reasons for the stay on the territory of a Member State and the family's move to that state, the child's nationality, the place and conditions of attendance at school, linguistic knowledge and the family and social relationships of the child in that State must be taken into consideration; taking account of all the circumstances specific to each individual case.

${ }^{113}$ Also, it is important to notice tht the EU's concept of habitual residence leads to a singular habitual residence, unlike some national laws, e.g. English law.

${ }^{114}$ Art. 14 of Croatian PILA. 
capacity by the law of the country where the contract was concluded, the other party to the contract has to be aware of their incapacity or not aware thereof as a result of negligence. ${ }^{115}$ So, according to the Art. 13, in cases where the contract is concluded between the persons who are in the same state and the other party acted in a good faith, incapacity is determined by lex loci actus. Although well grounded, this might not be the best solution with regard to sport related contracts with minor athletes, as will be discussed infra.

\section{Sport Related Contracts With Minors}

Sport related contracts with minors nowadays attract a lot of attention. Namely, bearing in mind huge and speculative investments and the costs of transfers of players, clubs are displaying a tendency to conclude contracts with potential young stars at a very young age. ${ }^{116}$ On the other hand, parents acting as legal representatives of their children, often drawn by the amount of money circulating in sport, accept offers they do not entirely comprehend. This is especially true where the international element is included.

In such cases, the question of the applicable law for such contracts, considering particulary its protective provisions, is a logical consequence. Namely, Croatian law has recently been changed toward the more efficient protection of minor athletes ${ }^{117}$ which might not be the case with some other laws. Thus, from the point of view of a club or a sponsor, compared to such other law, Croatian law might seem restrictive and not so attractive. Consequently, it is to be expected that the other contractual party, typically financially superior one, will try to impose its own choice of the applicable law with the purpose

\footnotetext{
${ }^{115}$ Van Calster, G.: European Private International Law, Hart Publishing, Oxford and Portland, 2013, p. 141.

${ }^{116}$ Youngest player with whom a professional player's contract (lasting 10 years) has been signed was only 18 months. Closing contracts with 7 or 8 years old is becoming an usual practice. See: Ugovori s djecom - sve češći, Deutsche Welle, 17. 8. 2011.

117 When closing a sport related contract between a minor and certain natural or legal person, it will be signed by the legal representative of the child but with the prior authorisation of the Social Welfare. It lasts only until the minor reaches the age of majority, i.e. until 18 years old. Such a contract has to satisfy the form of notary act and the public notary has the duty to explain to the parties the consequences of the contract they are about to sign. See: Arts. 19 and 20(1) to (3) of the Labour Act, Arts. 85(2), 99(1) and (5), 101(1),(3) and (4) of the Family Law Act and Art. 53 of the Notary Public Act. However, there are still some vagueness regarding the delineation between these Acts, in the sense that there is no consensus (yet) as to the hierarchy of these Acts. Consequently, there is an open space for some misinterpretations. See: Hrabar, op. cit, note 18; Ivančić-Kačer, op. cit, note 1. Medić, I.: Pravna zaštita maloljetnih sportaša u kontekstu prava EU, Zbornik radova PF u Splitu, Vol. 52, 4/2015, pp. 1105-1138.
} 
of evading the application of Croatian substantial law provisions. The question is, in the context of the existing legal system, is it possible? What is the applicable law in sports related contracts of minors and does the choice of foreign law as the law applicable for contract allow evasion of Croatian protective legislation?

There is no separate set of rules with regard to the determination of the applicable law for sport related contracts with minors. The options are the same irrespective of whether the sport related contract is concluded between adults or one of the parties is a minor. It is so, because the law applicable for the parent-child relationship is in charge of the protection of a minor in such cases. Thus, from a Croatian point of view, if a contract is concluded between a Croatian national (minor athlete) represented by a Croatian national (parent) and the foreign club, it is impossible to evade the application of Croatian protective legislation, since Croatian substantial law is applicable. If the contract is concluded between a foreign national (minor athlete) represented by a foreign national (parent) with a Croatian club, the law applicable to a parent-child relationship is determined according to the provisions of the Hague 1996 Convention. ${ }^{118}$ According to Art. 17 of this Convention, „The exercise of parental responsibility is governed by the law of the State of the child's habitual residence. If the child's habitual residence changes, it is governed by the law of the State of the new habitual residence. ". ${ }^{119}$ So, if, at the moment of the conclusion of the contract, the child has their habitual residence abroad, the law of that country is applicable. If the child's habitual residence changes to Croatia, Croatian law is applicable. In any case, the law applicable to contract will not make any difference with respect to the protection of a minor athlete.

\footnotetext{
${ }^{118}$ Hague Convention on Jurisdiction, Applicable Law, Recognition, Enforcement and Cooperation in respect of Parental Responsibility and Measures for the Protection of Children, concluded 19 October 1996. Available at: http://www.hcch.net .

${ }^{119}$ What does it mean in practice is best displayed by the following example. If, according to the law of the new habitual residence, parent must secure prior approval from the competent authority in order to act on behalf of a child, such approval will have to be secured even if it was not needed according to the law of the country of the child's previous habitual residence. However, not everything is so simple. If, e.g. due to the marriage concluded before the change of habitual residence, law of the state of the child's new habitual residence considers this child as an adult, is the parent still entitled to exercise parental responsibility over that child? Or, does the parental responsibility expires because the law of the State of the child's new habitual residence stipulates so? See: Nygh, P.: The new Hague child protection convention, International Journal of Law, Policy and Family, Vol. 11, No. 3, Dec. 1997, p. 354.
} 
But there is another question which might be of interest here. What is the legal nature of provisions of Croatian protective legislation? Are these rules just internally mandatory rules or, they may be considered as overriding mandatory rules? Although it is a difficult question to answer and there is no case law available, we will make an attempt. According to the definition of the overriding mandatory rules in CJEU ruling in an Arblade case, ${ }^{120}$ which in our view can be applied universally, overriding mandatory rules are "... provisions the respect for which is regarded as a crucial by a country for safeguarding its public interests, such as political, social or economic organisation, to such an extent that they are applicable to any situation falling within their scope, irrespective of the law otherwise applicable ...". What is crucial for Croatian legal order is determined by Croatian Constitution ${ }^{121}$ and it certainly includes the protection of minors. ${ }^{122}$ It is the duty of the State to protect minors and to ensure that they are not employed if they are under the age precribed by law and that they are not forced to work if it is detrimental to their health or morals. ${ }^{123}$ Thus, in our view, Croatian protective law provisions may be applied as overriding mandatory rules in cases where the law of the child's habitual residence does not offer adequate protection of a minor athlete.

Considering the authority of a parent to enter into business transactions on behalf of a child, Art. 19 of the Hague 1996 Convention also takes into account the fact that the third party is not always aware or informed that the child's habitual residence is in another state and that the person acting as the child's legal represtentative may not be entitled to that representation according to the law of that other state. Consequently, any legal transaction concluded between persons present on the territory of the same state, between the (unaware or uninformed) third party and the person acting as a child's legal representative will be considered valid and the third party will not be held liable unless the third party knew or should have known that the parental responsibility was governed by another law. ${ }^{124}$

\footnotetext{
${ }^{120}$ Joined Cases C-369/96 and C-376/96 [1999] ECR I-8453. In order for a rule to be classified as overriding mandatory rule it has to cumulatively fulfill the interest and the overriding criteria. See: Kunda, op. cit, note 62, pp. 217-219. Bonomi, A.: Conversion of the Rome Convention on Contracts into an EC Instrument: Some Remarks on the Green Paper of the EC Community, Yearbook of Private International Law, Vol. 5, 2003, p. 48.

${ }^{121}$ Ustav RH, NN RH No 56/90, 135/97, 8/98, 113/00, 124/00, 28/01, 41/01, 55/01, 776/10, $85 / 10,05 / 14$.

${ }^{122}$ Arts. 63-65 of the Constitution.

${ }^{123}$ Art. 65 of the Constitution.

${ }^{124}$ See: Lagarde, P.: Explanatory Report on the Hague Conventionn on Jurisdiction, Appli-
} 
This problem might be mitigated by a request to the authorities of the Contracting State of the child's habitual residence, or of the Contracting State where a measure of protection has been taken to deliver the person having parental responsibility or to the person entrusted with protection of the child's person or property at his or her request a certificate indicating the capacity in which that person is entitled to act and the powers conferred upon him or her. ${ }^{125}$

\section{Conclusion}

As this short presentation shows, dealing with contracts in the sporting context is a challenging subject matter. There is a variety of sport related contracts with their own specific features and there is no law which is tailored exclusively for contracts in the sporting context, at substantial or at private international law level. Some of those contracts are (or very similar to) business contracts, while some other may be characterised as employment contracts. Irrespective of their (obviously different) legal nature, the determination of the applicable law is based on their contractual nature and as such oriented towards enhancing predictability and certainty as to the applicable law by a distinct commitment to party autonomy.

Due to the "specificity of sport" and the well developed body of autonomous sports rules, sports related contracts often contain an arbitration clause. It is of great importance with respect to the determination of the applicable law since the choice of law in arbitration proceedings is more flexible and includes a non-state law also. Thus, parties may agree on the application of lex sportiva or ex aequo et bono dispute resolution.

The only exception in relation to the precedence of the parties' choice is contained in Rule 58 of the CAS Code, which provides for a mandatory hierarchy of the applicable legal framework, which the parties cannot change. Therefore, in the Appeal Arbitration Procedure the "applicable regulations" always come first, regardless of the will of the parties. If the "applicable regulations" contain a reference to a national law, then the scope of application of the national law thus invoked must be delineated from the law chosen by the parties. CAS jurisprudence gives a good overview of the possible approaches and the questions left to the law chosen by the parties.

cable Law, Recognition, Enforcement and Cooperation in respect of Parental Responsibility and Measures for the Protection of Children, 1996, p. 583.

${ }^{125}$ Art. 40(1) of the Hague 1996 Convention. 
In the absence of parties' choice there are different solutions in different sources of law. Rome I Regulation provides an exhaustive catalogue of contracts fixing the applicable law and leaves some leeway to ex post determination by courts. Arbitration procedure provides for the application of lex arbitri with some exceptions depending on the circumstances of the case.

Due to the "specificity of sport", i.e. the inherent characteristics of sport which set it apart from other economic and social activities, it would be good to have one coherent set of rules to govern numerous and often complicated contractual relationships within sport. Obviously, it is just a wishfull thinking since such a regime is not realistic. Civil courts are not suitable to deal with lex ludica or lex sportiva, nor are different arbitral tribunals suitable to protect different national or international interests. Thus, it all comes down to the most appropriate delineation of the two regimes. Rather than within the ambit of private international law, adjustments should be made within national laws, in order to enhance protection of minor athletes and aligne their provisions with the CJEU rulings. Consistency in jurisprudence on behalf of CAS, as well as on behalf of national courts is also an imperativ.

Some claim that sport and the law are two separate realms and that the law operates in a manner that is totally incompatible with the operation of sport. ${ }^{126}$ On the other hand, an internal legal structure of sports proves different. It shows that both areas equally need the structure and the rules in order to produce desirable objective.

${ }^{126}$ Foster, K.: Developments in Sporting Law, in: Allison, L. (ed.): The Changing Politics of Sport, Manchester University Press, 1993, p. 106. 